О. І. Лук'янчук, кандидат юридичних наук,

судовий експерт сектору автотоварознавчих досліджень

лабораторії товарознавчих, гемологічних, економічних,

будівельних, земельних досліджень та оціночної діяльності,

Київський науково-достідний експертно-

криміналістичний центр МВС України, м. Київ

ORCID: https://orcid.org/0000-0001-5003-5752

\title{
ПРАВОМІРНІСТЬ РЕЦЕНЗУВАННЯ ВИСНОВКУ ЕКСПЕРТА В СУДОВОМУ ПРОЦЕСІ
}

\begin{abstract}
Mema статті - науково обгрунтувати теоретичні засади правового регулювання інституту рецензування висновків судового експерта, а також правомірність подання рецензії на висновок експерта в межах розгляду справи в суді. Методологія. Достовірність отриманих результатів і висновків забезпечено сукупністю методів загальнонаукового і конкретно-наукового рівнів. Зокрема, з позиції матеріалістичної діалектики розглянуто юридичну природу висновку судового експерта як процесуального джерела доказів. Із застосуванням методів формальної логіки (аналіз, синтез, аналогія, індукція та дедукція) визначено правовий статус рецензії в судово-експертній діяльності. Застосуванням порівняльно-правового методу, аналогії на практичних прикладах засвідчено помилковість сприйняття процедури рецензування висновків експерта учасниками процесу. Наукова новизна. Уперше запропоновано дефініцію процедури рецензування в контексті судово-експертної діяльності. Окреслено виключні обставини, за яких проводиться рецензування висновків судового експерта, обгрунтовано неприпустимість поширення практики «оскарження» висновку судового експерта через замовлення рецензії на нього. Висновки. У процесі розгляду питання здійснено комплексний аналіз судової практики та нормативно-правових актів, що регулюють процедуру рецензування висновків судових експертів. З’ясовано, що метою рецензування висновків судових експертів є вдосконалення професійної майстерності експертів, підвищення якості та обгрунтованості їх висновків. При цьому наголошено, що рецензування не проводиться для спростування чи підтвердження висновків експерта, а рецензія не може бути використана як джерело доказів у будь-якому виді судочинства. Аргументовано недопустимість процедури рецензування висновків судового експерта в досудовому розслідуванні та судовому процесі. Доведено, що рецензія на висновок судового експерта має розглядатися судом як неналежний та недопустимий доказ і не повинна братися до уваги. Окреслено законні способи спростування результатів досліджень, викладених у висновку судового експерта.

Ключові слова: судова експертиза; судово-експертна діяльність; висновок експерта; рецензія; рецензування; рецензування висновку судового експерта; процедура рецензування висновку судового експерта.
\end{abstract}

\section{Вступ}

В умовах реформування судової гілки влади, а також дедалі більшої ролі принципу процесуальної рівності і змагальності сторін у судовому процесі особливої ваги набуває судова експертиза - дослідження на основі спеціальних знань у галузі науки, техніки, мистецтва, ремесла тощо об'єктів, явищ і процесів із метою надання висновку з питань, що $\epsilon$ або будуть предметом судового розгляду (Pro sudovu ekspertyzu: Zakon Ukrainy, 1994, st. 1).

Висновок експерта являє собою чи не найвагоміший засіб доказування в судовому процесі; а в кримінальному провадженні становить процесуальне джерело доказів (Kryminalnyi protsesualnyi kodeks Ukrainy: Zakon Ukrainy, 2012, st. 84).

Суд, керуючись законом, оцінює висновки експертизи за своїм внутрішнім переконанням, що грунтується на всебічному, повному й неупередженому розгляді всіх обставин справи та доказів в їх сукупності.
I хоча на висновок експерта поширюються загальні правила оцінювання доказів, проте він, маючи специфічні риси, суттєво вирізняється серед інших засобів доказування, оскільки обгрунтований спеціальними знаннями, якими не володіють учасники судового процесу. Але останнім часом трапляються ситуації, коли одна зі сторін у справі, зазвичай незадоволена результатами дослідження, викладеними у висновку експерта, намагається «оскаржити» його. Для цього як своєрідну допомогу, у вигляді інструменту для оцінювання доказів, які містить у собі висновок експерта, до суду, а то й на стадії досудового розслідування (у кримінальних провадженнях) подає рецензію на висновок експерта, виконану за відповідну плату, на замовлення сторони судового процесу, 3 посиланням на те, що суд, так само як і сторони у справі, не має відповідних спеціальних знань і не може його оцінити (Tkachenko, 2018, s. 293). Кінцева мета цього полягає у тому, щоб суд призна- 
чив повторну експертизу або, оцінюючи висновок, відхилив його.

Навколо правового статусу рецензії і порядку рецензування висновків судових експертів дискусії точаться багато десятиліть. Ця тема останніми роками була предметом обговорення круглих столів і семінарів за участю представників науково-дослідних установ судової експертизи, Науково-дослідного інституту інтелектуальної власності НАПрН України, Асоціації правників України, суддів, адвокатів, науковців.

Окреслену проблематику в межах теорії доказів і в контексті істинності та достовірності висновків експертів через їх рецензування розглядали у своїх працях С. С. Бичкова, Ж. В. Васильєва-Шаламова, В. Г. Гончаренко, Ф. М. Джавадов, Н. І. Клименко, Є. Г. Коваленко, О. М. Моїсєєв, Є. Ю. Свобода, Є. А. Ткаченко, В. В. Федчишина, В. Д. Юрчишин. Проте й досі бракує одностайності у цьому питанні.

Вітчизняні й зарубіжні фахівці висвітлювали різні аспекти досліджуваної тематики, як-от: зрозумілість мови висновків криміналістів для суддів і учасників процесу (Howes, Kirkbride, Kelty, Julian, \& Kemp, 2013); експертна оцінка в галузі криміналістики (Ballantyne, Edmond, \& Found, 2017, Aug.); оцінювання висновку експерта під час розслідування злочинів (Viter, 2019); судово-медична експертиза: сучасні проблеми правового регулювання, управління, процедура і оцінювання експертних висновків (Ivanova, \& Dyakonova, 2019); висновок судової експертизи: вивчення практики складання звітів експертами (Bali, Edmond, Ballantyne, Kemp, \& Martire, 2020); демонстрація надійності через прозорість: основа наукової обгрунтованості на допомогу вченим і юристам у кримінальному судочинстві (Carr, Piasecki, \& Gallop, 2020); тлумачення судових висновків фахівцями кримінальної юстиції: ті самі докази тлумачаться по-різному (van Straalen, de Poot, Malsch, \& Elffers, 2020).

Проте сьогодні для однозначного розуміння та застосування на практиці бракує грунтовних досліджень обставин, що зумовлюють процедуру рецензування висновку судового експерта, та правомірності замовлення рецензії на висновок судового експерта у вітчизняному судочинстві, що й визначає актуальність обраної тематики.

\section{Мета й завдання дослідження}

Мета статті - науково обгрунтувати теоретичні засади правового регулювання інституту рецензування висновків судового експерта, а також правомірність подання рецензї на висновок експерта в межах розгляду справи в суді.

Для досягнення цієї мети необхідно вирішити такі завдання: проаналізувати судову практику та нормативно-правові акти, що регламентують процес рецензування висновків судового експерта;

окреслити критерії рецензування висновків судового експерта як засобу контролю за їх якістю для реалізації принципів удосконалення професійної майстерності, підвищення обгрунтованості висновків та їх доказового значення;

виробити пропозиції щодо однозначного розуміння застосування норм матеріального права, які регулюють процедуру рецензування висновку судового експерта з метою унеможливлення подання рецензій на висновок судового експерта як належний і допустимий доказ.

\section{Виклад основного матеріалу}

Доказами в цивільному, господарському процесі та адміністративному судочинстві $є$ будь-які дані, на підставі яких суд установлює наявність або відсутність обставин (фактів), що обгрунтовують вимоги і заперечення учасників справи, та інших обставин, які мають значення для вирішення справи. Висновок експерта є одним із засобів, за допомогою якого встановлюються такі дані (Tsyvilnyi protsesualnyi kodeks Ukrainy: Zakon Ukrainy, 2004, st. 76; Hospodarskyi protsesualnyi kodeks Ukrainy: Zakon Ukrainy, 1991, st. 73; Kodeks administratyvnoho sudochynstva Ukrainy: Zakon Ukrainy, 2005, st. 72).

У кримінальному провадженні доказами $€$ фактичні дані, отримані в передбаченому КПК України порядку, на підставі яких слідчий, прокурор, слідчий суддя і суд встановлюють наявність чи відсутність фактів та обставин, що мають значення для кримінального провадження та підлягають доказуванню (Kryminalnyi protsesualnyi kodeks Ukrain: Zakon Ukrainy, 2012, st. 84, ch. 1). Висновок експерта - докладний опис проведених експертом досліджень і зроблені за їх результатами висновки, обгрунтовані відповіді на запитання, що їх поставила особа, яка залучила експерта, або слідчий суддя чи суд, що доручив проведення експертизи (st. 101, ch. 1), становить процесуальне джерело доказів (st. 84, ch. 2).

Вирізняють процесуальні джерела доказів специфічні риси, зумовлені їх сутністю (Klymenko, 2007, s. 160): формуються вони на основі використання спеціальних знань, являючи собою вивідне, а не інформативне, як інші особисті докази (показання), знання. У висновку експерта доказове значення передусім має розумовий умовивід, якого дійшов експерт за результатами дослідження.

Проте сьогодні вже узвичаїлась практика, засвідчують фахівці (Tkachenko, 2018, s. 294; Krut, 2013, s. 36), коли суддя, не маючи жодних аргументів, щоб спростувати висновок судової експер- 
тизи, чи можливості поставити його під сумнів, послуговується рецензію на цей висновок i, трапляється, долучає ії до матеріалів справи, оцінюючи як належний і допустимий доказ.

Наприклад, Шевченківський районний суд м. Києва, ухвалюючи вирок від 27 квітня 2020 р. у справі 761/5301/17, узяв до уваги рецензіі, надані стороною захисту для спростування висновків судових експертиз, які суд визнав належними та допустимими доказами в розумінні ст. 85 і 86 КПК України (Vyrok Shevchenkivskoho raionnoho sudu m. Kyieva vid 27.04.2020 u spravi № 761/5301/17).

Рецензію досить часто надають суду під удаваним тлумаченням висновку експерта зрозумілою для суддів і учасників процесу мовою (Howes, Kirkbride, Kelty, Julian, \& Kemp, 2013; Tkachenko, 2018 , s. 293), що якнайменше некоректно, оскільки висновок експерта і так має бути доступний для розуміння судом (Carr, Piasecki, \& Gallop, 2020).

Отже, сьогодні слід констатувати законодавчу невизначеність рецензування висновку експерта.

У загальновживаному тлумаченні рецензування являє собою дію за значенням рецензувати, тобто писати рецензію, відзив на що-небудь (Busel (Uklad. i Holov. red.), 2005, s. 1219). Рецензія (нім. die Rezension від лат. recensio) - аргументований критичний відгук, найчастіше про твір літератури, мистецтва; його синонім - ревю (від англ. Review - огляд, оцінка) (Baryshpolets, 2014, s. 65).

В юридичній площині рецензію розглядають як рукопис, відгук на будь-який твір, проєкт (зокрема й законопроєкт), дисертацію, що містить оцінку праці, а також відповідні пропозиції та рекомендації рецензента (Shemshuchenko (Red.), 2003, s. 532).

У контексті судово-експертного дослідження рецензування - науково обгрунтований синтез досліджень, викладених у висновку судової експертизи, специфічний метод управління якістю й організацією проведення експертних досліджень (Fedchyshyna, 2014, s. 110).

Слід зауважити, що процедуру рецензування передбачено законодавством України про оцінку майна, майнових прав і професійну оціночну діяльність. Полягає вона в критичному розгляді звіту про оцінку майна (акта оцінки майна) і наданні висновків щодо його повноти, правильності виконання та відповідності застосованих процедур оцінки майна вимогам нормативно-правових актів з оцінки майна в порядку, визначеному Законом України (Pro otsinku maina, mainovykh prav ta profesiinu otsinochnu diialnist $v$ Ukraini: Zakon Ukrainy, 2001), Національним стандартом № 1 (Natsionalnyi standart № 1, 2003), іншими нормативно-правовими актами з оцінки майна.
Так, «рецензування звіту про оцінку майна здійснюється на вимогу особи, яка використовує оцінку майна та іiі результати для прийняття рішень, у тому числі на вимогу замовників (платників) оцінки майна, органів державної влади та органів місцевого самоврядування, судів та осіб, які заінтересовані в неупередженому критичному розгляді оцінки майна, а також за власною ініціативою суб'єкта оціночної діяльності» (Natsionalnyi standart № 1, 2003, р. 62). При цьому «рецензія не повинна містити власного висновку про вартість об’єкта оцінки» (р. 64), тобто рецензія не може замінити висновок про оцінку майна.

Убачається, що прийняттям саме цих двох нормативно-правових актів (Pro otsinku maina, mainovykh prav ta profesiinu otsinochnu diialnist $v$ Ukraini: Zakon Ukrainy, 2001; Natsionalnyi standart № 1, 2003) започатковано практику замовлення рецензій на висновки судових експертів за принципом аналогії закону.

Але така практика неправомірна, оскільки, по-перше, згадані нормативно-правові акти визначають правовідносини щодо оцінки майна або майнових прав, та виражаються у формі звіту, складеного суб'єктом оціночної діяльності суб'єктом господарювання або у формі акта оцінки майна, складеного органом державної влади чи місцевого самоврядування, а по-друге, для недопущення застосування саме такої аналогії 2004 р. ст. 4 Закону України «Про оцінку майна, майнових прав та професійну оціночну діяльність в Україні» доповнено частиною четвертою: «Діяльність судових експертів, пов'язана 3 оцінкою майна, здійснюється на умовах і в порядку, передбачених Законом України «Про судову експертизу», з урахуванням особливостей, визначених цим Законом щодо методичного регулювання оцінки цього майна. Інші положення цього Закону не поширюються на судових експертів».

Зважаючи на неоднозначність застосування норм матеріального права як судами, так і сторонами у справі щодо процедури рецензування висновків судового експерта, з метою забезпечення подальшого здійснення структурних економічних реформ, запровадження додаткових механізмів для прискорення соціально-економічного розвитку України, підвищення добробуту населення, гармонійного розвитку регіонів, упровадження й далі європейських стандартів життя та зміцнення держави Президент України 8 листопада 2019 р. підписав Указ «Про невідкладні заходи 3 проведення реформ та зміцнення держави» № $837 / 2019$.

Відповідно Кабінету Міністрів України було поставлено завдання у сфері забезпечення прав i свобод людини і громадянина (Pro nevidkladni 
zakhody, 2019, p. 1, pidp. 3«b») до 31 грудня 2020 p. розробити та внести на розгляд Верховної Ради України законопроєкт про внесення змін до деяких законодавчих актів України щодо запровадження рецензування висновку судового експерта.

Крім того, набув чинності Порядок проведення рецензування висновків судових експертів, затверджений наказом Міністерства юстиції України від 3 лютого 2020 р. № 335/5, який визначив процедуру проведення та оформлення результатів рецензування висновків судових експертів науково-дослідних установ судових експертиз Міністерства юстиції України, судових експертів, які не $є$ працівниками державних спеціалізованих установ, а також проєктів висновків фахівців, що мають намір отримати кваліфікацію судового експерта.

у цьому підзаконному нормативному акті визначено мету рещензування висновків судових експертів (удосконалення професійної майстерності експертів, підвищення якості та обгрунтованості їх висновків), мету рецеензування проєктів висновків (визначення рівня підготовки фахівців, які мають намір отримати кваліфікацію судового експерта) і підстави рецензування висновків, проєктів висновків (план рецензування висновків судових експертів науково-дослідних установ судових експертиз Міністерства юстиції України; договір або план щодо підготовки (стажування) фахівця, який має намір отримати (підтвердити) кваліфікацію судового експерта). При цьому рецензування висновків $\epsilon$ компетенцією співробітників науково-дослідних установ судових експертиз Міністерства юстиції України, які мають кваліфікацію судового експерта 3 тієї експертної спеціальності, за якою складено поданий на рецензування висновок, та не менше ніж трирічний стаж експертної роботи.

Рецензія має містити розгорнуту характеристику висновку щодо його відповідності вимогам нормативно-правових актів із питань судово-експертної діяльності та методикам проведення судових експертиз.

I найголовніше - рецензування не проводиться з метою спростувати чи підтвердити висновок (Poriadok provedennia retsenzuvannia vysnovkiv, 2020, rozd. I, p. 2).

До того ж Положенням про Експертно-кваліфікаційну комісію МВС та порядок проведення атестації судових експертів Експертної служби MBC, затвердженим наказом МВС України від 21 вересня 2020 р. № 675, визначено, що «звернення про здійснення рецензування висновку експерта, складеного за результатами судової експертизи або експертного дослідження, та (або) надання юридичної оцінки висновку експерта лишаються без розгляду, оскільки порушені в них питання не належать до компетенції Експертної служби MBC, про що повідомляються ініціатори таких звернень (заявники)» (Polozhennia pro Ekspertnokvalifikatsiinu komisiiu MVS, 2020, rozd. II, hl. 6, p. 5).

Отже, рецензії на висновок судового експерта як процесуального документа не існує. А особа, яка їі складає, не несе жодної відповідальності, крім моральної за свої міркування стосовно оцінки висновку експерта, його правильності й обгрунтованості, оскільки висловлює лише особисту суб'єктивну думку.

Саме так у своєму вироку від 26 жовтня 2020 р. у справі № 753/6685/19 висловився Дарницький районний суд м. Києва: «... твердження захисника Биковича Ю. В. про порушення процедури проведення експертизи та численні недоліки під час іiї проведення, а також доводи, викладені у Рецензії на висновок експерта № 8-5/1980 від 11.01.2018 року (т. 2 а. п. 114-136), є суб'єктивними твердженнями зазначених осіб, які не несуть жодної відповідальності за хибність таких тверджень» (Vyrok Darnytskoho raionnoho sudu m. Kyieva vid 26.10.2020 u spravi № 753/6685/19).

Варто зауважити, що у процесуальному законодавстві сформульовано загальне правило, яке характеризує допустимість доказів - обставини справи, що за законом мають бути підтверджені певними засобами доказування, не можуть підтверджуватись іншими засобами доказування (Tsyvilnyi protsesualnyi kodeks Ukrainy: Zakon Ukrainy, 2004, st. 78).

Про процесуальний статус рецензії на висновок експерта йдеться і в Постанові Верховного Суду у складі колегії суддів Другої судової палати Касаційного цивільного суду від 17 червня 2020 р. у справі № 761/19866/14-ц: «рецензування не є процесуальною дією і складений за його результатами документ не має доказового значення» (Postanova Verkhovnoho Sudu u skladi kolehii suddiv Druhoi sudovoi palaty Kasatsiinoho tsyvilnoho sudu vid 17.06.2020 u spravi № 761/19866/14-ts).

Розглядаючи цивільну справу № 753/5208/19, Київський апеляційний суд у своїй постанові від 19 листопада 2020 р. зауважив: «рецензія експерта Круть О. В. від 08 липня 2020 року не відповідає зазначеним вище вимогам, а саме всупереч положенням Порядку підставою для рецензування висновку фізико-хімічної експертизи матеріалів документів від 30 квітня 2020 року № 9501 стало звернення представника позивача - адвоката Паливоди В. Д. Також рецензію підготовлено особою, яка не $є$ працівником державних спеціалізованих установ.

Крім того, колегія суддів вважає необхідним зазначити, що рецензія не $\epsilon$ тим доказом в розу- 
мінні закону, який спростовує висновок експертизи, оскільки процедура рецензування висновків експертів не має за мету вплинути на його оцінку в судовому процесі. Інститут рецензування висновків судових експертів $€$ інструментом внутрішньої процедури перевірки якості та обгрунтованості висновків, що подаються з метою отримання та підтвердження кваліфікації судового експерта. Метою рецензування висновків судових експертів згідно з пунктом 2 Порядку є «вдосконалення професійної майстерності експертів, поліпшення якості та обгрунтованості їх висновків». Таким чином, процедура рецензування висновків експертів не має за мету вплинути на його оцінку в судовому процесі, а Порядок не передбачає надання рецензії на висновок експерта на розгляд суду чи інших учасників судового процесу» (Postanova Kyivskoho apeliatsiinoho sudu vid 19.11.2020 u spravi № 753/5208/19).

Водночас позиція прихильників рецензування висновків судового експерта, які вважають таку процедуру чи не єдиною можливістю для спростування результатів дослідження, викладених у висновку експерта, убачається доволі дискусійною.

По-перше, незалежність судового експерта та правильність його висновку забезпечуються: визначеним законом порядком призначення судового експерта; забороною під загрозою передбаченої законом відповідальності втручатися будь-кому в проведення судової експертизи; існуванням установ судових експертиз, незалежних від органів, що здійснюють оперативно-розшукову діяльність, органів досудового розслідування та суду; створенням необхідних умов для діяльності судового експерта, його матеріальним і соціальним забезпеченням; кримінальною відповідальністю судового експерта за давання свідомо неправдивого висновку та відмову без поважних причин від виконання покладених на нього обов'язків; можливістю призначення повторної судової експертизи; присутністю учасників процесу в передбачених законом випадках під час проведення судової експертизи (Pro sudovu ekspertyzu: Zakon Ukrainy, 1994, st. 4).

По-друге, жодні докази не мають для суду заздалегідь встановленої сили. Суд оцінює належність, допустимість, достовірність кожного доказу окремо, а також достатність і взаємний зв'язок доказів у їх сукупності (Tsyvilnyi protsesualnyi kodeks Ukrainy: Zakon Ukrainy, 2004, st. 89, ch. 2; Hospodarskyi protsesualnyi kodeks Ukrainy: Zakon Ukrainy, 1991, st. 86, ch. 2; Kodeks administratyvnoho sudochynstva Ukrainy: Zakon Ukrainy, 2005, st. 90, ch. 2 i 3 ).

Висновок експерта не обов'язковий для особи або органу, яка здійснює провадження, але незгода з висновком експерта повинна бути вмотивована у відповідних постанові, ухвалі, вироку (Kryminalnyi protsesualnyi kodeks Ukrainy: Zakon Ukrainy, 2012, st. 101, ch. 10).

По-третє, для роз'яснення і доповнення висновку експерт може бути викликаний у суд і йому можуть бути поставлені запитання щодо висновку, який він надав. У такому разі експерт зобов'язаний з'явитися до суду за його викликом та роз'яснити свій висновок, відповісти на запитання суду та учасників справи (Kryminalnyi protsesualnyi kodeks Ukrainy: Zakon Ukrainy, 2012, st. 356; Tsyvilnyi protsesualnyi kodeks Ukrainy: Zakon Ukrainy, 2004, st. 356; Kodeks administratyvnoho sudochynstva Ukrainy: Zakon Ukrainy, 2005, st. 221).

Крім того, судовий експерт як учасник процесу, що несе кримінальну відповідальність за давання завідомо неправдивого висновку й інші види юридичної відповідальності, має права та обов'язки, визначені процесуальним законодавством України та Законом України «Про судову експертизу» (Sopova, 2018, s. 77).

Суддя (суд), керівник органу досудового розслідування, адвокат або учасник справи (сторони кримінального провадження) мають право подати звернення про можливі порушення судовим експертом вимог нормативно-правових актів, які регламентують судово-експертну діяльність, та (або) методик проведення судових експертиз i експертних (сертифікаційних) досліджень. У разі вмотивованості звернення голова Експертно-кваліфікаційної комісії МВС або його заступник видає доручення на проведення службової перевірки (Polozhennia pro Ekspertno-kvalifikatsiinu komisiiu MVS, 2020, rozd. II, hl. 6, p. 4). Результат службової перевірки, приміром, може бути використано для обгрунтування призначення повторної експертизи.

На виконання Указу Президента України (Pro nevidkladni zakhody, 2019), яким поставлено завдання (p. 1, pidp. 3«b») розробити законопроєкт про внесення змін до деяких законодавчих актів України щодо створення системи самоврядування судових експертів, запровадження рецензування висновку судового експерта та визначення граничних строків проведення судових експертиз, Міністерство юстиції України започаткувало громадське обговорення проєкту Закону України «Про судово-експертну діяльність», який планується внести на розгляд Верховної Ради України у третьому кварталі 2021 p.

Оприлюднений проєкт Закону містить, зокрема, таку норму:

«3. Рецензія на висновок експерта передбачає аналіз та коментування основних положень висновку експерта шляхом узагальненого і аргументованого його оцінювання з точки зору відпо- 
відності вимогам чинного законодавства та методикам проведення судової експертизи.

Метою рецензування висновків експерта $є$ вдосконалення його професійної майстерності, поліпшення якості та обгрунтованості його висновків. Рецензування не проводиться з метою спростування чи підтвердження висновків експерта.

Рецензія не може бути використана в якості джерела доказів у будь-якому виді судочинства.» (Pro sudovo-ekspertnu diialnist: proiekt Zakonu Ukrainy, n. d., st. 29, ch. 3).

3 огляду на викладене пропонуємо під процедурою рецензування висновку судового експерта розуміти аналіз і коментування основних положень висновку експерта шляхом узагальненого і аргументованого його оцінювання з позиції відповідності вимогам чинного законодавства та методикам проведення судової експертизи.

\section{Наукова новизна}

Уперше запропоновано дефініцію процедури рецензування в контексті судово-експертної діяльності. Окреслено виключні обставини, за яких проводиться рецензування висновків судового експерта, та обгрунтовано неприпустимість поширення практики «оскарження» висновку судового експерта через замовлення рецензії на нього.

\section{Висновки}

1. Проаналізовано судову практику та нормативно-правові акти, що регламентують процес рецензування висновків судового експерта, і з'ясовано, що судова експертиза є основним засобом доказування, який сприяє всебічному, повному й об’єктивному дослідженню обставин справ. Забезпечується він основними принципами судово-експертної діяльності, що полягають у законності, незалежності, об'єктивності й повноті дослідження та гарантуються Законом України «Про судову експертизу» і процесуальним законодавством України.

2. Окреслено критерії рецензування висновків судового експерта як засобу контролю за їх якістю для реалізації принципів удосконалення професійної майстерності, підвищення обгрунтованості висновків та їх доказового значення. При цьому констатовано, що Порядок проведення рецензування висновків судових експертів, затверджений наказом Міністерства юстиції України від 3 лютого 2020 р. № 335/5, єдиний підзаконний нормативно-правовий акт, що регулює процедуру рецензування висновків судових експертів. Цей Порядок встановлює чіткий перелік підстав для проведення рецензування висновків судових експертів, серед яких такої підстави, як складання рецензії на замовлення учасників судового процесу немає.

3. Вироблено пропозиції щодо однозначного розуміння застосування норм матеріального права, які регулюють процедуру рецензування висновку судового експерта з метою унеможливлення подання рецензій на висновок судового експерта як належний і допустимий доказ. При цьому:

сформульовано дефініцію процедури рецензування висновку судового експерта, під якою слід розуміти аналіз і коментування основних положень висновку експерта шляхом узагальненого i аргументованого його оцінювання з позиції відповідності вимогам чинного законодавства та методикам проведення судової експертизи;

аргументовано, що метою рецензування висновків експерта $€$ вдосконалення його професійної майстерності, підвищення якості та обгрунтованості його висновків. Наголошено, що рецензування не проводиться з метою спростувати чи підтвердити висновки експерта, а рецензія не може бути використана як джерело доказів у будь-якому виді судочинства;

обгрунтовано, що практика подання учасниками судового процесу рецензій на висновки судових експертів, а також прийняття на їх основі рішень про призначення додаткової чи повторної експертизи суперечить законодавству України. 3 позиції закону, рецензія на висновок судового експерта має розглядатися судом як неналежний та недопустимий доказ і не повинна братися до уваги.

\section{References}

Bali, A. S., Edmond, G., Ballantyne, K. N., Kemp, R. I., \& Martire, K. A. (2020). Communicating forensic science opinion: An examination of expert reporting practices. Science \& Justice: journal of the Forensic Science Society, 60 (3), $216-224$. DOI: https://doi.org/10.1016/j.scijus.2019.12.005.

Ballantyne, K. N., Edmond, G., \& Found, B. (2017, Aug.). Peer review in forensic science. Forensic Science International, 277, 66-76.

DOI: $10.1016 /$ j.forsciint.2017.05.020.

Baryshpolets, O. T. (2014). Ukrainskyi slovnyk mediakultury. Kyiv: Milenium. 196 s. [in Ukrainian].

Busel, V. T. (Uklad. i Holov. red.). (2005). Velykyi tlumachnyi slovnyk suchasnoi ukrainskoi movy: 250 000. Kyiv; Irpin: Perun. VIII, 1728 s. [in Ukrainian].

Carr, S., Piasecki, E., \& Gallop, A. (2020). Demonstrating reliability through transparency: A scientific validity framework to assist scientists and lawyers in criminal proceedings. Forensic science international, 308, 110110. DOI: https://doi.org/10.1016/j.forsciint.2019.110110. 
Fedchyshyna, V. V. (2014). Retsenzuvannia vysnovkiv sudovykh ekspertiv - metod vnutrividomchoho kontroliu upravlinnia ekspertnoho zabezpechennia pravosuddia Ukrainy. Ekonomika ta derzhava, 9, 109-112. Uziato z http:// www.economy.in.ua/pdf/9_2014/28.pdf [in Ukrainian].

Hospodarskyi protsesualnyi kodeks Ukrainy: Zakon Ukrainy № 1798-XII-VR. (1991). Uziato z https://zakon.rada.gov.ua/ laws/show/1798-12\#Text [in Ukrainian].

Howes, L. M., Kirkbride, K. P., Kelty, S. F., Julian, R., \& Kemp, N. (2013). Forensic scientists' conclusions: how readable are they for non-scientist report-users? Forensic science international, 231 (1-3), 102-112. DOI: https://doi.org/10.1016/j.forsciint.2013.04.026.

Ivanova, E. V., \& Dyakonova, O. G. (2019). Sudebnaia ékspertiza v otnoshenii zhivykh lits: sovremennye problemy zakonodatel'nogo regulirovaniia, naznacheniia, proizvodstva i otsenki ékspertnykh zakliucheniü [Forensic medical examinations of living persons: modern problems of legal regulation, administration, procedure, and the evaluation of expert opinions]. Sudebno-meditsinskaia ekspertiza, 62 (5), 9-12.

DOI: https://doi.org/10.17116/sudmed2019620519.

Klymenko, N. I. (2007). Sudova ekspertolohiia: kurs lektsii: navch. posib. dlia stud. yuryd. spets. vyshch. navch. zakl. Kyiv: In Yure. 526 s. [in Ukrainian].

Kodeks administratyvnoho sudochynstva Ukrainy: Zakon Ukrainy № 2747-IV-VR. (2005). Uziato z https://zakon.rada. gov.ua/laws/show/2747-15\#Text [in Ukrainian].

Kryminalnyi protsesualnyi kodeks Ukrain: Zakon Ukrainy № 4651-VI. (2012). Uziato z https://zakon.rada.gov.ua/laws/ show/4651-17\#n1191 [in Ukrainian].

Krut, O. V. (2013). Shchodo retsenzii na vysnovok sudovoho eksperta ta pravomirnosti yii vykorystannia v sudochynstvi. Advokat, 2 (149), 36-37 [in Ukrainian].

Natsionalnyi standart № 1 «Zahalni zasady otsinky maina i mainovykh prav»: zatv. postanovoiu Kabinetu Ministriv Ukrainy № 1440. (2003). Uziato $\mathrm{z}$ https://zakon.rada.gov.ua/laws/show/1440-2003-p\#top [in Ukrainian].

Polozhennia pro Ekspertno-kvalifikatsiinu komisiiu MVS ta poriadok provedennia atestatsii sudovykh ekspertiv Ekspertnoi sluzhby MVS: zatv. nakazom MVS Ukrainy № 675. (2020). Uziato z https://zakon.rada.gov.ua/laws/show/ z0022-21\#Text [in Ukrainian].

Poriadok provedennia retsenzuvannia vysnovkiv sudovykh ekspertiv: zatv. nakazom Ministerstva yustytsii Ukrainy № 335/5. (2020). Uziato z https://zakon.rada.gov.ua/laws/show/z0131-20\#Text [in Ukrainian].

Postanova Kyivskoho apeliatsiinoho sudu vid 19.11.2020 u spravi № 753/5208/19. Uziato z https://reyestr.court.gov.ua/ Review/93184282 [in Ukrainian].

Postanova Verkhovnoho Sudu u skladi kolehii suddiv Druhoi sudovoi palaty Kasatsiinoho tsyvilnoho sudu vid 17.06.2020 u spravi № 761/19866/14-ts. Uziato z https://reyestr.court.gov.ua/Review/90111557 [in Ukrainian].

Pro nevidkladni zakhody z provedennia reform ta zmitsnennia derzhavy: Ukaz Prezydenta Ukrainy № 837/2019. (2019). Uziato z https://zakon.rada.gov.ua/laws/show/837/2019\#Text [in Ukrainian].

Pro otsinku maina, mainovykh prav ta profesiinu otsinochnu diialnist v Ukraini: Zakon Ukrainy № 2658-III. (2001). Uziato z https://zakon.rada.gov.ua/laws/show/2658-14\#top [in Ukrainian].

Pro sudovo-ekspertnu diialnist: proiekt Zakonu Ukrainy. (n. d.). Uziato z https://minjust.gov.ua/news/ministry/ministerstvo-yustitsii-ukraini-vinosit-na-publichne-gromadske-obgovorennya-proekt-zakonu-ukraini-pro-sudovo-ekspertnu-diyalnist [in Ukrainian].

Pro sudovu ekspertyzu: Zakon Ukrainy № 4038-XII. (1994). Uziato z https://zakon.rada.gov.ua/laws/show/4038-12\#Text [in Ukrainian].

Shemshuchenko, Yu. S. (Red.). (2003). Yurydychna entsyklopediia: v 6 t. Kyiv: «Ukrainska entsyklopediia» im. M. P. Bazhana, 1998. T. 5: P-S. Kyiv: [b. v.]. 736 s.: il. [in Ukrainian].

Sopova, K. (2018). Vysnovky ekspertiv, patentnykh povirenykh ta inshykh fakhivtsiv u spravakh shchodo prav na torhovelni marky. Teoriia i praktyka intelektualnoi vlasnosti, 6, 71-82. Uziato z http://nbuv.gov.ua/UJRN/Tpiv_2018_6_8 [in Ukrainian].

Tkachenko, Ye. A. (2018). Retsenzuvannia vysnovkiv sudovykh ekspertiv yak neformalni praktyky - yikh protsesualnyi status ta otsinka v kryminalnomu provadzhenni. Chasopys Kyivskoho universytetu prava, 4, 293-297. Uziato z https:// journals.indexcopernicus.com/api/file/viewByFileId/670046.pdf [in Ukrainian].

Tsyvilnyi protsesualnyi kodeks Ukrainy: Zakon Ukrainy № 1618-IV-VR. (2004). Uziato z https://zakon.rada.gov.ua/laws/ show/1618-15\#Text [in Ukrainian].

van Straalen, E. K., de Poot, C. J., Malsch, M., \& Elffers, H. (2020). The interpretation of forensic conclusions by criminal justice professionals: The same evidence interpreted differently. Forensic science international, 313, 110331. DOI: https://doi.org/10.1016/j.forsciint.2020.110331.

Viter, D. V. (2019). Do pytannia otsinky vysnovku eksperta pid chas rozsliduvannia zlochyniv u sferi finansuvannia sotsialnykh tsilovykh prohram. Prykarpatskyi yurydychnyi visnyk, 1 (26), 208-212 [in Ukrainian]. DOI: https://doi.org/10.32837/pyuv.v0i1(26).40.

Vyrok Darnytskoho raionnoho sudu m. Kyieva vid 26.10.2020 u spravi № 753/6685/19. Uziato z https://reyestr.court.gov. ua/Review/92422042 [in Ukrainian].

Vyrok Shevchenkivskoho raionnoho sudu m. Kyieva vid 27.04.2020 u spravi № 761/5301/17. Uziato z http://reyestr.court. gov.ua/Review/71570540 [in Ukrainian]. 


\section{Список використаних джерел}

Bali, A. S., Edmond, G., Ballantyne, K. N., Kemp, R. I., \& Martire, K. A. (2020). Communicating forensic science opinion: An examination of expert reporting practices. Science \& Justice: journal of the Forensic Science Society, 60 (3), $216-224$. DOI: https://doi.org/10.1016/j.scijus.2019.12.005.

Ballantyne, K. N., Edmond, G., \& Found, B. (2017, Aug.). Peer review in forensic science. Forensic Science International, 277, 66-76.

DOI: $10.1016 /$ j.forsciint.2017.05.020.

Баришполець, О. Т. (2014). Украӥнський словник медіакультури. Київ: Міленіум. 196 с.

Бусел, В. Т. (Уклад. і Голов. ред.). (2005). Великий тлумачний словник сучасної української мови: 250 000. Київ; Ірпінь: Перун. VIII, 1728 с.

Carr, S., Piasecki, E., \& Gallop, A. (2020). Demonstrating reliability through transparency: A scientific validity framework to assist scientists and lawyers in criminal proceedings. Forensic science international, 308, 110110. DOI: https://doi.org/10.1016/j.forsciint.2019.110110.

Федчишина, В. В. (2014). Рецензування висновків судових експертів - метод внутрівідомчого контролю управління експертного забезпечення правосуддя України. Економіка та держава, 9, 109-112. Узято з http://www. economy.in.ua/pdf/9_2014/28.pdf.

Господарський процесуальний кодекс України: Закон України № 1798-XII-BP. (1991). Узято з https://zakon.rada.gov. ua/laws/show/1798-12\#Text.

Howes, L. M., Kirkbride, K. P., Kelty, S. F., Julian, R., \& Kemp, N. (2013). Forensic scientists' conclusions: how readable are they for non-scientist report-users? Forensic science international, 231 (1-3), 102-112. DOI: https://doi.org/10.1016/j.forsciint.2013.04.026.

Ivanova, E. V., \& Dyakonova, O. G. (2019). Sudebnaia ékspertiza v otnoshenii zhivykh lits: sovremennye problemy zakonodatel'nogo regulirovaniia, naznacheniia, proizvodstva i otsenki ékspertnykh zakliucheniǐ [Forensic medical examinations of living persons: modern problems of legal regulation, administration, procedure, and the evaluation of expert opinions]. Sudebno-meditsinskaia ekspertiza, 62 (5), 9-12. DOI: https://doi.org/10.17116/sudmed2019620519.

Клименко, Н. І. (2007). Судова експертологія: курс лекцій: навч. посіб. для студ. юрид. спец. вищ. навч. закл. Київ: Ін Юре. 526 c.

Кодекс адміністративного судочинства України: Закон України № 2747-IV-BP. (2005). Узято з https://zakon.rada.gov. ua/laws/show/2747-15\#Text.

Кримінальний процесуальний кодекс України: Закон України № 4651-VI. (2012). Узято з https://zakon.rada.gov.ua/ laws/show/4651-17\#n1191.

Круть, О. В. (2013). Щодо рецензії на висновок судового експерта та правомірності їі використання в судочинстві. Адвокат, 2 (149), 36-37.

Національний стандарт № 1 «Загальні засади оцінки майна і майнових прав»: затв. постановою Кабінету Міністрів України № 1440. (2003). Узято з https://zakon.rada.gov.ua/laws/show/1440-2003-п\#top.

Положення про Експертно-кваліфікаційну комісію МВС та порядок проведення атестації судових експертів Експертної служби MBC: затв. наказом МВС України № 675. (2020). Узято з https://zakon.rada.gov.ua/laws/ show/z0022-21\#Text.

Порядок проведення рецензування висновків судових експертів: затв. наказом Міністерства юстиції України № 335/5. (2020). Узято з https://zakon.rada.gov.ua/laws/show/z0131-20\#Text.

Постанова Київського апеляційного суду від 19.11.2020 у справі № 753/5208/19. Узято з https://reyestr.court.gov.ua/ Review/93184282.

Постанова Верховного Суду у складі колегії суддів Другої судової палати Касаційного цивільного суду від 17.06.2020 у справі № 761/19866/14-ц. Узято з https://reyestr.court.gov.ua/Review/90111557.

Про невідкладні заходи з проведення реформ та зміцнення держави: Указ Президента України № 837/2019. (2019). Узято $з$ https://zakon.rada.gov.ua/laws/show/837/2019\#Text.

Про оцінку майна, майнових прав та професійну оціночну діяльність в Україні: Закон України № 2658-III. (2001). Узято з https://zakon.rada.gov.ua/laws/show/2658-14\#top.

Про судово-експертну діяльність: проєкт Закону України. (н. д.). Узято з https://minjust.gov.ua/news/ministry/ ministerstvo-yustitsii-ukraini-vinosit-na-publichne-gromadske-obgovorennya-proekt-zakonu-ukraini-pro-sudovoekspertnu-diyalnist.

Про судову експертизу: Закон України № 4038-XII. (1994). Узято з https://zakon.rada.gov.ua/laws/show/4038-12\#Text.

Про судово-експертну діяльність: проєкт Закону України. Узято з https://minjust.gov.ua/news/ministry/ministerstvoyustitsii-ukraini-vinosit-na-publichne-gromadske-obgovorennya-proekt-zakonu-ukraini-pro-sudovo-ekspertnudiyalnist.

Шемшученко, Ю. С. (Ред.). (2003). Юридична енциклопедія: в 6 т. Київ: «Українська енциклопедія» ім. М. П. Бажана, 1998. Т. 5: П-С. Київ: [б. в.]. 736 с.: іл.

Сопова, К. (2018). Висновки експертів, патентних повірених та інших фахівців у справах щодо прав на торговельні марки. Теорія і практика інтелектуальної власності, 6, 71-82. Узято з http://nbuv.gov.ua/UJRN/Tpiv_2018_6_8.

Ткаченко, Є. А. (2018). Рецензування висновків судових експертів як неформальні практики - їх процесуальний 
статус та оцінка в кримінальному провадженні. Часопис Київського університету права, 4, 293-297. Узято 3 https://journals.indexcopernicus.com/api/file/viewByFileId/670046.pdf.

Цивільний процесуальний кодекс України: Закон України № 1618-IV-BP. (2004). Узято з https://zakon.rada.gov.ua/ laws/show/1618-15\#Text.

van Straalen, E. K., de Poot, C. J., Malsch, M., \& Elffers, H. (2020). The interpretation of forensic conclusions by criminal justice professionals: The same evidence interpreted differently. Forensic science international, 313, 110331. DOI: https://doi.org/10.1016/j.forsciint.2020.110331.

Вітер, Д. В. (2019). До питання оцінки висновку експерта під час розслідування злочинів у сфері фінансування соціальних цільових програм. Прикарпатський юридичнй вісник, 1 (26), 208-212. DOI: https://doi.org/10.32837/pyuv.v0i1(26).40.

Вирок Дарницького районного суду м. Києва від 26.10.2020 у справі № 753/6685/19. Узято з https://reyestr.court.gov. ua/Review/92422042.

Вирок Шевченківського районного суду м. Києва від 27.04.2020 у справі № 761/5301/17. Узято 3 http://reyestr.court. gov.ua/Review/71570540.

Стаття надійшла до редакції 18.03.2021

\author{
O. Lukianchuk, Ph.D in Law, \\ Forensic Expert of Autocommodity Research Sector \\ of Commodity, Gemological, Economic, Construction, Land Researches \\ and Evaluation Activities Laboratory, \\ Kyiv Scientific Research Forensic Center, MIA of Ukraine, \\ Kyiv, Ukraine \\ ORCID: https://orcid.org/0000-0001-5003-5752
}

\title{
A LEGALITY OF PEER REVIEW OF FORENSIC EXPERTS REPORT IN A JUDICIAL PROCESS
}

\begin{abstract}
The purpose of the article is to substantiate scientifically the theoretical basics of the legal regulation of a peer reviewing institution of forensic expert report and a legality of giving peer review for forensic opinion as part of the court case consideration. Methodology. A validity of obtained results and conclusions had been ensured by totality of methods at general scientific and specific scientific levels. In particular, in terms of materialistic dialectic a legal nature of forensic expert report as procedural source of evidence had been considered. A legal status of a peer reviewing in forensic expert activities had been determined by using of formal logic methods (analysis, synthesis, analogy, induction and deduction). The perception fallacy of parties to proceedings in procedure of expert reports peer reviewing had been witnessed on practical examples by usage of comparative legal method and analogy. Scientific novelty. The peer reviewing procedure definition in the context of forensic expert activities performance has been first introduced. Exceptional circumstances during performing of peer review of forensic expert report had been outlined and an inadmissibility of appealing practice for forensic experts report by ordering its peer review had been substantiated. Conclusions. Complex analysis of judicial practice, domestic legislation and general documents regulating the procedure of peer reviewing of forensic expert reports had been implemented during the issue considering. It had been established that the aim of peer reviewing of forensic expert report was to improve its professional excellence, quality and substantiation but not to confirm or deny it; and the peer review could not be used as a source of evidence in any type of proceedings. An inadmissibility of peer reviewing procedure performance for forensic experts report during pre-trial investigation and judicial process had been argued. It had been established that the peer review of forensic experts report should be considered by the court as inadequate and inadmissible evidence and should not be taken into account. Lawful ways for denying of investigation results presented in the forensic experts report had been outlined.
\end{abstract}

Keywords: forensic examination; forensic expert activities; forensic expert report; peer review; peer reviewing; peer reviewing of forensic expert report; procedure of peer reviewing of forensic expert report. 
Е. И. Лукьянчук, кандидат юридических наук, судебный эксперт сектора автотовароведческих исследований лаборатории товароведческих, геммологических, экономических, строительных, земельных исследований и оиеночной деятельности, Киевский научно-исследовательский экспертнокриминалистический центр МвД Украины, г. Киев ORCID: https://orcid.org/0000-0001-5003-5752

\title{
ПРАВОМЕРНОСТЬ РЕЦЕНЗИРОВАНИЯ ЗАКЛЮЧЕНИЯ ЭКСПЕРТА В СУДЕБНОМ ПРОЦЕССЕ
}

\begin{abstract}
Целью статьи является научное обоснование теоретических основ правового регулирования института рецензирования заключений судебного эксперта, а также правомерность подачи рецензии на заключение эксперта в рамках рассмотрения дела в суде. Методология. Достоверность полученных результатов и выводов обеспечена совокупностью методов общенаучного и конкретно-научного уровней. В частности, с позиции материалистической диалектики рассмотрена юридическая природа заключения судебного эксперта как процессуального источника доказательств. С применением методов формальной логики (анализ, синтез, аналогия, индукция и дедукция) определен правовой статус рецензии в судебно-экспертной деятельности. Путем применения сравнительно-правового метода, аналогии на практических примерах подтверждена ошибочность восприятия процедуры рецензирования заключения эксперта участниками процесса. Научная новизна. Впервые предложено дефиницию процедуры рецензирования в контексте проведения судебно-экспертной деятельности. Определены исключительные обстоятельства, при которых проводится рецензирование заключения судебного эксперта и обоснована недопустимость распространения практики «обжалования» заключения судебного эксперта путем заказа рецензии на него. Выводы. В процессе рассмотрения вопроса осуществлен комплексный анализ судебной практики и нормативно-правовых актов, регулирующих процедуру рецензирования заключений судебных экспертов. Установлено, что целью рецензирования заключения эксперта является совершенствование его профессионального мастерства, улучшение качества и обоснованности выводов. При этом отмечено, что рецензирование не проводится для опровержения или подтверждения выводов эксперта, а рецензия не может быть использована в качестве источника доказательств в любом виде судопроизводства. Аргументирована недопустимость процедуры рецензирования заключений судебного эксперта в досудебном расследовании и судебном процессе. Установлено, что рецензия на заключение судебного эксперта должна рассматриваться судом как ненадлежащее и недопустимое доказательство и не может приниматься во внимание. Определены законные способы для опровержения результатов исследований, изложенных в заключении судебного эксперта.

Ключевые слова: судебная экспертиза; судебно-экспертная деятельность; вывод эксперта; рецензия; рецензирование; рецензирование вывода судебного эксперта; процедура рецензирования вывода судебного эксперта.
\end{abstract}

